\title{
Psychological aspects of the content strategies of the Russian media
}

\author{
Tatiana I. Frolova \\ Lomonosov Moscow State University, Moscow, Russia
}

\begin{abstract}
This article looks at the content strategies of the Russian media and discusses whether they conform to humanitarian values. The content strategies that prevailed in different eras and the social and psychological effects that they engendered are compared. Special attention is paid to conflicts of values and other negative consequences of the communicative incompetence of the media in Russia; this lack of competence poses a threat to the information security of society.
\end{abstract}

Keywords: anthropocentric scientific paradigm, current media processes, humanitarian media agenda, content strategies, lack of communicative competence, information security

\section{Humanitarian values in the modern context}

The information era and "media reality" have brought about global conditions forcing one out of one's traditional environment and into the sphere of virtual images, virtual relations, and media structures that often differ greatly from one's initial interests.

At present, the humanistic mission of journalism is facing a severe test. The revolutionary media processes that have been taking place in recent decades have a great influence on the possibility of maintaining and developing humanitarian values. The long-standing historic contingence between man's social nature and the humanitarian, communicative and information mission of the media is now at odds with the commercial interests of property owners as well as with many social and cultural processes originating in digitalization and the widespread use of the Internet. The changes taking place within media landscapes are quite controversial; they are not always viewed as unequivocally positive phenomena.

The creation of information superhighways and multimedia provides great opportunities for developing one's powers, useful communication, education and enlightenment, interaction and creative cooperation, civil rights and participative democracy; we have every reason to talk about the social and anthropological transformations resulting from the rapidly changing information structure of 
mass communications. Absolutely positive assessments of this process were typical in its early stage, before all the possible situations, risks, and consequences were defined. Further on, at the turn of this century and mainly in the first decade of it, not only the theorists of mass communication and communication science but also the broad public began to express their concern about the controversial nature of transformations and trends that pose a threat to human development: the dramatic commercialization and privatization of the media; the commoditization of information products, which brings about the reduction of the public sphere; the segmentation of society; virtual escapism; cultural apathy; the individual's vulnerability to low-quality information; total infotainment; the decline in the written cultural tradition and of reasoning abilities.

Philosophers, sociologists, and psychologists have arrived at the conclusion that mass communication as a peculiar social phenomenon is nothing but a communication surrogate, a simulacrum that fails to tackle the tasks of understanding and of creative cooperation, which remain the essential conditions for human development. Consequently, there is no point in setting excessively high goals for mass communication and in expecting that the development of the mass media will automatically bring humanity closer to perfection. True communication is marked by making human life a top value; but the communicative strategies arising from information consumerism and from providing high profits to the owners of mass media contribute to the devaluation of human life. However neither the nature of the mass media nor the peculiarities of modern cyber-journalism are to be regarded as factors that make human-development goals unreachable; on the contrary, they bring about the possibility of reaching such goals.

Another important factor that brings into focus the subject of the humanitarian values of the media in a psychology context is connected with the massive transformation of the Russian social environment. Russian society is facing the active renewal of values and priorities. There is hardly any overlap among the key values; the conflicts are no longer resolved along the lines of old priorities and ideals. Such changes are an integral part of any transition period; however, the culture of prioritizing values, which helps prevent enormous inner shocks, is not developed in our society. The social history of Russia in regard to human development is unique and dramatic; the psychological tension has always been high: "Man doesn't feel good here"; "Russians have never loved the human. Never been proud of it. Never built monuments to it. The human as such is not so interesting" (Giryonok, 2010, p. 180). As opposed to "strongmen," the Russian cultural elite has always believed that grieving and rejoicing with people to be its moral responsibility and has always followed this principle.

If we consider just the contemporary, post-Soviet period in Russian history, we have to admit that the social price of the reforms was too high and incommensurable with the positive humanitarian achievements realized (Khalturina \& Korotaev, 2006; Rimashevskaya, 2003; Ryvkina, 2001; Zaslavskaya, 2002). “The Russian cross," "the great criminal revolution," "the new poor" have become the cultural symbols of the new Russia, proving that "the subject turning to the symbol when faced with an uncertain situation ... can be viewed as the zone of proximal development in the cognitive activity of both humanity as a whole and a particular individual" (Veraksa, 2012, p. 69). 
No matter how advanced and promising the social changes are from a historical perspective, one can't but admit that human potential and moral health have been damaged greatly and not recovered yet. "The drama of changes" (Ryvkina, 2001) can be observed above all in personal disorientation: a feeling of helplessness, passiveness and apathy, anxiety, and nostalgia for the past.

Another context for the development of today's communicative practice is the turn to the human being as the general vector of modern liberal research. Such statements as "the subject of the human is becoming the general subject of all sciences," "the humanitarian paradigm of science," "the anthropological grounds of post-nonclassical science," "accepting the anthropocentric concept of society," and "overcoming social realism and technocracy" have been proclaimed as the principles for understanding global problems. The multidimensionality of human beings brings about a new image of social reality and leads to viewing society through the prism of an individual and determining the essence of "human existentials" (Ananyev, 2010; Gurevich, 2010). The human being has been the central subject in philosophy and psychology from the times of the ancient thinkers. But the 20th century and especially the beginning of the 21 st century were marked by a true "anthropological boom," which demonstrated fundamental changes in the approach to understanding the human being, and by the establishment of a number new science disciplines (Barulin, 2007; Berger, Berger, \& Collins, 2004; Frolov, 1989; Guseinov, 2009; Mamardashvili, 1996). The global acknowledgement of general humanitarian values was preceded by a lengthy process of elaborating them in the contexts of philosophy, ethics, and psychology ${ }^{\star}$ and by the social and cultural expertise of humanity.

Special attention should be paid to the concept of human development, which resulted from the postwar search for peace, harmony, and the well-being of humans. In the 1990s this concept served as the basis for the UN Development Program (UN Development Program website: http://www.un.org/ru/development/). The key points of the concept are as follows: well-being is not limited to material aspects and should be assessed by the ability of people to lead lives that they consider worthy; human development reflects the expansion of human choices; the key measures of human development are long life, education, and material well-being; to lead a decent life people do not need ever-increasing income; steady human development involves equal access to development opportunities, and the observance of human rights is the essential condition for that; development level and cultural peculiarities must not serve as an excuse for violating human rights. The destiny of any national society is determined by the status of human potential in it. Russian scientists accept this concept on the whole but stress the fact that the "the UN trinomial" (income, health, and education) emphasizes these conditions of human development, while the question of the aim and essence of development remains unanswered. It therefore makes sense to use a broader list of characteristics of hu-

* Special attention in this connection should be paid to prominent thinkers of the 20th century: the representatives of Russian religious philosophy (N. A. Berdyaev, L. Shestov, S. L. Frank), of the phenomenological and existential schools of philosophy (E. Husserl, M. Heidegger, K. Jaspers, J. P. Sartre), of humanistic psychology (E. Fromm, A. Maslow, K. Yung, V. Frankl), and of hermeneutics. 
man potential including both physical and mental health, on which overall human capability depends; readiness to have a family and bring up children; skills and qualifications; level of adaptation to social infrastructure; attitudes toward culture and values; and psychological competence (Yudin, 2007). These components embrace not so much the economic as the psychological and especially the cultural, spiritual, and moral sides of human existence. The importance of these characteristics to human development causes them to be regarded as the objective form of humanitarian values.

\section{Establishment of the humanitarian media agenda}

As we can see, the need for information strategies that conform to the psychological status of society is critical. This need is reinforced by the transformation of the national media system: "Having readily accepted commercialization challenges, the commercial media model forced out many socially and culturally meaningful points of the agenda by actively promoting the new culture of consumption" (Vartanova, 2010). The links among the psychological aspects of the media, masscommunication trends, and actual media practice can be analyzed at various levels and from a variety of aspects.

From a historical point of view, Russia's expertise in putting together a humanitarian agenda is undoubtedly interesting. Certain traditions of Russian journalism can serve as cultural ties to and provide the value basis for today's humanitarian agenda, the vitality of which depends on more than just the general level of competence of the journalist community. Its integral component is the collective unconscious. Before the Revolution, the Russian intelligentsia was united by the idea of social service; the charity press, which provided the public arena for defining the humanistic grounds of a future multinational democratic society, was in bloom.

The "social topic" was always present in the Soviet press. The nature of the social relations of the time, the ideological pressure, the paternalistic culture, the imposition of collectivist morals-all significantly altered the essence of the social and personal elements of society and brought journalism, under tight control, down to reporting on social and living matters (The problematics of newspaper presentations, 1975; The problematics of the media, 2008). However, the Soviet period and Soviet journalism formulated many valuable principles that are rooted deeply in social conscience: social protection, mutual respect, personal honesty, the common person's dignity and work, fairness, responsibility for fellow citizens, sincerity and unselfishness in person-to-person relationships. Only recently has Russian society realized that the collapse of the old social order was not only a historically based change of regimes but also a major psychological loss, and first of all it was the loss of inner moral stability. New consumer values and personal opportunities do not make up for the lost friendliness, fairness, and feeling of security.

In the post-Soviet period the humanitarian journalistic agenda went through a number of transformations. At the turn of the 1990s the discovery of new topics and of whole new spheres of life significantly increased the degree of emotion in the media. All the most urgent problems were voiced, social matters were discussed; however, further on the quality of the reporting on social and psychological issues went down dramatically. 
In the 1990s the coverage of personal problems and social links was in decline. The politicization of the media and the dispersal of ownership pushed personal relations out of the focus of public attention. While putting together their communicative strategies, the leading media placed their stakes on political influence, often leaving no room for "everyday drama." Only an occasional voice would call for turning to the person in the chaos of radical changes, but personal space on the whole remained empty. The human was replaced with the idea.

In the mid-1990s, a different process emerged. Commercialization, the rapid development of the mass press and television, the prioritization of large circulations and high ratings resulted in turning personal problems, which had always raised great public interest but had been forced out of the media arena by political and economic discourse, into a kind of teaser. Particular cases of personal interest in the mass press were numerous and varied but, at the same time, one-sided and quite primitive. Personal space was narrowed, simplified, and mutilated. On the one hand, scandals, sensations, domestic crimes, private life, and celebrity gossip got extensive coverage. Private life has always attracted attention and included existential problems; however, the mass media managed only to single out those matters and to raise public interest in them without discussing their essence. Television became the clearest illustration of this trend. The common person got pushed out of the mass-communication arena again, this time by business. On the other hand, the audience was attacked by all kinds of "useful information" and advice on consumer issues: household problems, sales of and overall demand for goods, fitness, travel, folk medicine, and so on. But there was still no place for the human being; usefulness was the essential point. Personal destiny in the new social reality remained a personal business rather than the object of public discourse. Despite the expansion of the humanitarian agenda, the ideological shallowness and the lack of values came at a high price both to the society and to the individual. The so-called pseudo-humanitarian agenda got its shape: despite the turn to the human being, it did not actually handle the problems of social organization, civic upbringing, moral support in situations of cultural trauma-that is, all the preconditions for the acquisition of personal meanings and the harmonization of personal relations. The new agenda was based on a general lack of balance and did not provide ways of acquiring balance. The public dissatisfaction with what "the newspapers say" and what the electronic media offered was so great that some researchers even came up with the thesis of the "asociality of press." The social consequences of this media alienation from personal problems in the 1990s turned out to be dramatic. Social topics did get press coverage, but in most cases no solutions were suggested, no hopes expressed, while demoralization, torpor, and disunity were aggravated and the feeling that the country would constantly have to balance on the verge of a disaster was promoted. Admonishments, sensationalism, reductionism, negativism, and other manipulation techniques prevailed in the new communication strategies.

At the start of the new millennium a new humanitarian agenda began to take shape. A lot had changed in the minds of the Russian people; a new psychological reality had started developing in regard to the media. New social subjects appeared in the general media, information/analysis weeklies, certain television programs, and Internet forums. At this time of intensive searching and the mastering of new 
creative methods and techniques, fundamental changes in graphic design and stylistic solutions, and continuous differentiation of typical models, solutions were found for humanitarian problems; these solutions varied in content, meaning, creative approach, and completion level. Journalists whose professional mission was to report on the problems of people on the basis of humanistic principles were singled out. The current situation presupposes that in the near future the volume and quality of the coverage of humanitarian topics will finally bring about serious changes in social communication, and the social communities that are now taking shape will be able to influence decision-making and contribute to the improvement of human and social development.

\section{Current content strategies}

Nevertheless, many obstacles to instituting these positive processes remain; one of the key factors is the lack of journalists' communicative competence. Quite often the attempts of those in charge to promote certain problems in the media in order to get onto the daily agenda are accompanied by a great degree of ignorance about the media and their internal principles and give rise to a public response that does not help in finding efficient solutions. Content-analysis research devoted to various aspects of social life in Russia, such as charity, gender issues, family conflicts, social isolation, resocialization of the elderly, which are covered in hundreds of thousands of media reports, has demonstrated that these reports are characterized by an incomplete life cycle (Donors Foundation, 2011; Frolova, 2012; Smirnova \& Frolova, 2011; Vartanova, Smirnova, Frolova, 2012).

Today media communications in Russia, as well as in the rest of the world, play a special role in modeling social problems-that is, in making sure that a problem that can become urgent for the society is granted public status and psychological legitimacy and receives due development, discussion, and the attention of the media, politicians, and the people. The success of any solution to a problem is determined by the amount and quality of public attention it receives.

However, the capacity of the media is limited; they cannot model all potential problems, which therefore have to compete to gain entrance into the print and broadcast media. Getting into and staying on the public agenda is controlled by "gatekeepers," among whom journalists hold a prominent position. The selection criteria include dramatic effect, originality, cultural and political preferences, but first and foremost the problem has to provide the press with constant coverage opportunities that meet newsroom standards. Communication processes and other professional and social contacts should be normalized between journalists and the people speaking on behalf of the resolution of specific problems (Sconfield, Meyer, Griffin, 2000).

The above-mentioned factors explain why many fundamental social problems, such as the deplorable state of the roads, domestic violence, alcoholism, the underdeveloped social infrastructure, common ignorance, lack of a healthy way of life, the tradition of disrespect to individuals, do not have the status of urgent problems in Russian society.

In respect to information security, the trends at the individual level are described as a "psychosomatic syndrome," which is "system-defined" and "multilevel" 
and is determined by a number of factors, among them: "the motivational factor (with the domination of the failure-avoidance motive and the unsatisfied self-approval need); the factor of the emotional-regulation disorders, represented by both excessive emotional repression and lack of emotional control" (Zinchenko \& Pervichko, 2012, p. 157). As a whole, the multilevel psychosomatic syndrome can be seen in the "one-dimensional modernization" of Russian society, Russian citizens' "anti-modernization behavior," and their devotion to outdated behavior patterns and the power of tradition. Particular concern is caused by research showing that "about 30\% of the teenage participants aged 13-17 demonstrated a much higher degree of emotional ill-being and even depressiveness than is expected of this age group" (Podolsky, Karavanova, Idobaeva, Haymans, 2011, p. 11).

Everyone is aware of these problems, but because they occur every day, day after day, somehow they are not news anymore. For example, the criminal images disseminated by the media are quite different from those presented by the statistics and, even more, by the actual crime scene. As a result, people develop groundless fears, and attempts to toughen the existing legislation get full support, whereas the true threats are hardly recognized. The paradox is that their commonness prevents us from combating them. The press may sporadically raise interest in such topics and thereby precipitate the most unexpected and negative psychological effects. The Russian audience is quite familiar with these "media tides," which cover up less noticeable but rather meaningful subjects. Thus, a vicious circle is created: society does not have enough information about the problem and does not realize its importance and as a result is unable to protect itself.

To complete the psychological landscape of the media, one should highlight another factor: drawing media attention to a problem is not the only task gatekeepers face, although this aspect is usually named as the key one. The mobilization of the society and the authorities conducted by means of the mass media and in other public arenas can bring collateral damage. Similar information may lose the appeal of novelty, after which the number of publications on a topic goes down. The regression of the problem can be observed, and for many years it becomes a painful but common issue in the society. At the inner level, people believe such a problem cannot be resolved. The plentitude of information flows leads to a superficial attitude toward the problem: the audience is aware of the matter but no action is taken; thus, psychologically, knowledge substitutes for action.

Another explanation is that, in an era of information overload and high-speed communication, people lack time and have almost no "extra sympathy" for news stories about the problems and sorrows of their fellow citizens. Today's audience still remembers the "glasnost" epoch, which provided access to endless negative information about the present and the past. No one could stay indifferent to those descriptions, and people who had experienced the emotional shock became the pillar of the radical transformations that followed. But shortly afterward a new notion came to life, chernukha (the seamy side), which at first denoted the expansion to extraordinary levels of information on crimes and emergency situations. However, further on, in the mind of the people, it came to denote any news bits concerning the social consequences of the political and economic reforms (low salaries, the collapse of the social sphere, declining birth rates, the spread of social diseases, and so forth); the vast majority of these news bits contained distressing and harsh 
factual information. Negativism had turned into the dominating communicative strategy for many media, and the audience had to escape from it in order to protect itself.

The emotional burnout of the Russian audience is a special topic. It can be explained by both the objective realia and the contemporary history of the Russian media, as well as by a number of other factors. One can find many examples of situations in which the carelessly chosen communicative strategies of the media prevented progress in covering urgent topics even after they became the focus of public attention (Frolova, 2009). Problems often fall out of notice because of the protection mechanisms of "super-subject activity." Zinchenko suggests that security be defined as "a system phenomenon involving various levels of subject and super-subject activity.... Each level is characterized by its own subjects of security as a type of activity, the subject being an individual or a group of individuals, a society, state or the world community" (Zinchenko, 2011, p. 13). When the society gives up on certain problems because of information dysfunction, the society becomes the collective subject of its own psychological security.

A media information build-up takes place when a topic no longer seems exotic, and the audience gets used to it (the legitimization stage); the topic can provoke an official response and be acknowledged at the level where decisions are made. However, sometimes in real life the decisions are taken before the psychological mobilization of the audience has been achieved; this process may hinder problem handling. When decisions are taken ahead of time society can be prevented from understanding the matter and from accepting solutions (for example, in the case of the "nano" issues).

Moreover, quite frequently both the society and the solutions are ready, but with intensive media coverage the official action plan (for example, demographic development) is subject to criticism by the public. Solutions imposed on society highlight the social and psychological conflict: everyone agrees with the definition of the problem, but there are not enough practical suggestions from society, and a consensus deficit can be observed. Consequently, society achieves consent "by contradiction," and the potential for public involvement is wasted on criticism and denial of the official action plan. For example, in the case of "maternity capital" (federal subsidies for multiple-child families), after the suggestion was debated and rejected, the feeling that the work had been done was created; thus, once again, knowledge and sympathy replaced practical action. A yet more significant example of pathology or information dysfunction is the so-called overheated problems; work on these problems stops at the stage of acknowledgement and legitimization. Recognized and accepted by society, they either are put aside for the sake of ostensibly more urgent issues (this situation was quite typical in the mid- and late 1990s, when all the basic solutions in the social sector were postponed and society was left in a state of cultural underdevelopment) or do not get timely and drastic solutions because of use of the "gradual approach" (this situation can be seen in the case of the never-ending sporadic "reformation" of the education system, which has actually brought about its collapse, and in the case of the alcoholism pandemic). Previously information dysfunction meant, for instance, the imbalance between the quality and amount of information in various types of media (for example, the fundamental debate about education in the professional media and hardly any 
data about it in the general media) or the artificially created leveling of a problem ("alcoholics cannot recover"), which postpones finding a solution; today the effort that leads to results at the stage of acknowledgement and legitimization is no longer enough.

Finally, possibly the most meaningful problem in today's humanitarian agenda is that the Russian people are unable to gain a footing in the sphere of national values. It is quite obvious that the results of polls concerning the most urgent problems of society differ greatly from the predominant topics of public discourse. Journalists often take a stance that the majority of their audience does not share. Besides, discourse that can be characterized as "patriotic," "catastrophic," or "apologetic" rarely reveals any striving for consent, partnership, or harmony. Our public sphere is inhumane and aggressive. And although this "polyphony" of social life can, to a certain extent, be viewed as a means of development, human life during a war of values acquires an extreme existential tension, giving rise to aggression, violence, and frustration. The media create a cult of a strong person who is able to overcome this tension, to succeed, to break through, a person strong enough to bypass and deny traditional human values. Quite often, by their actions, journalists justify an inhumane and even merciless attitude toward deviance; a perfect illustration is the popular format of "people's talk shows" on television.

The increasing redundancy of information about high-profile topics, the aggravating conversion of human problems into a commodity, the expanding split in values are the new realia of the media agenda that pose a threat to the information security of society. The lack of social, psychological, and values-based harmony in Russian society remains a significant factor hindering civilized development.

However, positive trends can undoubtedly be observed along the way as well. Vartanova points out that although the social sphere and civic institutions have found themselves in the rear guard of the transformation, the media still do have "significant potential for promoting this process [in] public circles" (Vartanova, 2010). Consequently, we have grounds for an optimistic prognosis.

\section{References}

Ananyev, B.G.(2010). Chelovek kak predmet poznania [ Humans as an object of cognition]. Sanct-Petersburg: Piter

Barulin, V. S. (2007). Social'no-filosofskaya antropologiya. Chelovek i obschectvennij mir [Social and philosophical anthropology. People and the social world]. Moscow: Academic Project; Alma Mater.

Berger, P. L., Berger, B., \& Collins, R. (2004). Lichnostno-orientirovannaya sociologiya [Personality-oriented sociology]. Moscow: Academic Project.

Donors Foundation. (2011). Doklad o sostoyanii institucional'noj blagotvoritel'nosti v Rossii 2011 [Report on the status of institutional charity in Russia - 2011]. Moscow: Donors Foundation.

Frolov, I. I. (1989). O cheloveke i gumanizme. Raboty raznyh let [Of humans and humanism. Selected works of different years]. Moscow: Politizdat.

Frolova, T. I. (2009). Chelovek v informacionnoj povestke dnya. Gumanitarnye tehnologii v zhurnalistike [Humans in the information agenda: Humanitarian techniques in journalism]. Moscow: ASI. 
Frolova, T. I. (Ed.). (2012). Zhurnalistika i zdorov'e nacii: Mediakommunikacii i chelovecheskoe razvitie [Journalism and the health of the nation: Media communications and human development]. Moscow: MSU Publishing House.

Giryonok, F. (2010). Udovolstvie myslit' inache [The pleasure of thinking differently]. Moscow: Academic Project; Peace Foundation.

Gurevich, P. S. ( 2010). Filosofskaya antropologiya [Philosophical anthropology]. Moscow: Omega-L.

Guseinov, A. A. (Ed.). (2009). Chelovek, nauka, gumanizm. K 80-letiyu so dnia rozhdeniia akademika I. T. Frolova [People. Science. Humanism. For Academician I. T. Frolov's 80th birthday]. Moscow: Nauka.

Khalturina, D. A., \& Korotaev, A. V. (2006). Russkij krest [The Russian cross]. Moscow: ComKniga.

Mamardashvili, M. K. (1996). Neobhodimost' sebya [Self-necessity]. Moscow: Labirint

Podolsky, A. I., Karavanova, O. A., Idobaeva, O. A., \& Haymans, P. (2011). Psihojemocional'noe blagopoluchie sovremennyh podrostkov: opyt mezhdunarodnogo issledovanija [Potential juvenile ill-being: An international research outcome]. Vestnik Moskovskogo Universiteta. Series 14, Psikhologia [The Moscow University Herald. Series 14. Psychology], 2, 9-20.

Problematika gazetnyh vystuplenij [The problematics of newspaper presentations] In V. D. Pel't (Ed.) (1975). Moscow: MSU Publishing House.

Problematika SMI: Informacionnaya povestka dnya [The problematics of the media: The information agenda] In Shkondina M.V., Vychuba G.S., Frolovoj T.I., (Eds.) (2008). Moscow: Aspect Press.

Rimashevskaya, N. M. (2003). Chelovek i reformy: Sekrety vyzhivaniya [People and reform: The secrets of survival]. Moscow: ISAPN RAN.

Ryvkina, R. V. (2001). Drama peremen [The drama of changes]. Moscow: Delo.

Smirnova, O. V., \& Frolova, T. I. (2011). Krizis sem'i: Analiz tekstov rossijskih SMI [The crisis of the family: An analysis of texts of the Russian media). Vestnik Moskovskogo Universitet., Series 10, Zhurnalistika [The Moscow University Herald. Series 14. Journalism], 1, 203-227.

Vartanova, E. L. (2010). Koncepciya modernizacii i SMI (SMI v menyayuschejsya Rossii) [The concept of modernization and the media (Media in a changing Russia)]. Moscow: Aspect Press.

Vartanova, E. L., Smirnova, O., \& Frolova, T. I. (2012). Gendernoe izmerenie politiki v povestke SMI [Changes in gender politics in the media agenda]. In The gender and media almanac. Moscow: MSU Publishing House.

Veraksa, A. N. (2012). Simvol kak sredstvo poznavatel'noj deyatel'nosti [Symbol as a means of cognitive activity]. Voprosy psihologii [Issues of psychology], 4, 62-70.

Yudin, B. G. (2007). Koncepciya chelovecheskogo potenciala [The concept of human potential]. Retrieved from http://zpujournal.ru/gum/prospects/articles/2007/Yudin/3/

Zaslavskaya, T. I. (2002). Societal'naya transformaciya rossijskogo obschecstva [The societal transformation of Russian society]. Moscow: Delo.

Zinchenko, Yu. P. (2011). Metodologicheskie osnovy psikhologii bezopastosti [The methodological basis for the psychology of security]. Nacionalnij psikhologicheskij zhurnal [National Psychological Journal], 2(6), 11-15.

Zinchenko, Yu. P., \& Pervichko, E. I. (2012). The methodology of syndrome analysis within the paradigm of "qualitative research" in clinical psychology. Psychology in Russia: State of the Art, 5, 157-184. doi: 10.11621/pir.2012.0010 